\title{
PHOSPHORUS AND POTASSIUM FERTILIZATION IN CREEPING PEANUT
}

\author{
Adubação com fósforo e potássio em amendoim de porte rasteiro
}

\begin{abstract}
Tiago Zoz ${ }^{1 *}$; Diego Augusto Fiorese ${ }^{2}$; Laercio Augusto Pivetta ${ }^{3}$; André Zoz ${ }^{4}$; Jardel Zoz ${ }^{5}$; Alan Mario Zuffo ${ }^{6}$
${ }_{1}^{1}$ Professor; Departamento de Agronomia; Universidade Estadual de Mato Grosso do Sul; zoz@uems.br ${ }_{2}^{2}$ Professor; Departamento de Agronomia; Universidade Federal de Mato Grosso; dafiorese@yahoo.com.br ${ }_{3}^{3}$ Professor; Departamento de Agronomia; Universidade Federal do Paraná; laerciopivetta@ufpr.br ${ }_{4}^{4}$ Mestrando; Departamento de Agronomia; Universidade Estadual de Mato Grosso do Sul; andre_zoz@hotmail.com ${ }^{5}$ Graduando; Departamento de Agronomia; Universidade Estadual de Mato Grosso do Sul; jardel_zoz@hotmail.com “6 Pós-Doutorando; Departamento de Agronomia; Universidade Estadual de Mato Grosso do Sul; alan_zuffo@hotmail.com
\end{abstract}

Artigo enviado em 29/03/2017, aceito em 18/07/2017 e publicado em 10/04/2018.

\begin{abstract}
Phosphorus $(\mathrm{P})$ and potassium $(\mathrm{K})$ fertilization can maximize the profitability of peanut cultivation. Therefore, the aim of this study was to evaluate the basic fertilization with $\mathrm{P}$ and $\mathrm{K}$ on the grain yield and production components of creeping peanut. The experiment was performed in a randomized block design, in a $2 \times 3+1$ factorial scheme. Two doses of $\mathrm{K}\left(30\right.$ and $60 \mathrm{~kg} \mathrm{ha}^{-1}$ of $\left.\mathrm{K}_{2} \mathrm{O}\right)$ and three levels of $\mathrm{P}\left(60,90\right.$ and $120 \mathrm{~kg} \mathrm{ha}^{-1}$ of $\left.\mathrm{P}_{2} \mathrm{O}_{5}\right)$ at sowing and an additional treatment without the basic fertilization were used, with four replicates. The cultivar Runner IAC 886was adopted. The following traits were evaluated: pod yield, grain yield, number of pods per plant, number of pods with grains per plant, the percentage of pods without grains, 100 grains weight and number of seeds per pod. $\mathrm{P}$ and $\mathrm{K}$ fertilization at sowing promote an increase in creeping peanut of about 38 and $49 \%$ in pod yield and grain yield, respectively. The highest values of pods with grains are observed with the application of $120 \mathrm{~kg} \mathrm{ha}^{-1}$ P.
\end{abstract}

Key-Words: Arachis hypogaea L., yield, Runner IAC 886.

Resumo - A adubação com fósforo $(\mathrm{P})$ e potássio $(\mathrm{K})$ pode maximizar a rentabilidade do cultivo do amendoim. Dessa forma, objetivou-se com este trabalho avaliar a adubação de base com P e K na produtividade dos grãos e nos componentes de produção do amendoim de porte rasteiro. $\mathrm{O}$ delineamento experimental utilizado foi de blocos ao acaso, dispostos em esquema fatorial 2 × $3+1$, sendo duas doses de $\mathrm{K}\left(30\right.$ e $60 \mathrm{~kg} \mathrm{ha}^{-1}$ de $\left.\mathrm{K}_{2} \mathrm{O}\right)$ e três doses de $\mathrm{P}$ (60, 90 e $120 \mathrm{~kg} \mathrm{ha}^{-1}$ de $\left.\mathrm{P}_{2} \mathrm{O}_{5}\right)$ na semeadura, mais um tratamento adicional sem adubação de base com $\mathrm{P}$ e $\mathrm{K}$, com quatro repetições. Utilizou-se a cultivar Runner IAC 886. Foram avaliados a produtividade das vagens, a produtividade dos grãos, o número de vagens por planta, número de vagens granadas por planta, a percentagem de vagens não granadas, massa de 100 grãos, o número de grãos por vagem. A adubação com $\mathrm{P}$ e $\mathrm{K}$ na semeadura promove aumento em torno de 38 e $49 \%$ na produtividade em vagens e de grãos do amendoim de porte rasteiro respectivamente. Os maiores valores de vagens granadas são verificados com a aplicação de $120 \mathrm{~kg} \mathrm{ha}^{-1} \mathrm{P}$.

Palavras-Chave - Arachis hypogaea L., produtividade, Runner IAC 886.

\section{INTRODUCTION}

Peanut (Arachis hypogaea $\mathrm{L}$ ) is an oilseed that has stood out in the global agriculture (GODOY et al., 2004). Its cultivation is mainly aimed at oil extraction. It can be consumed fresh or roasted and can also be used in the preparation of sweet dishes (MIRANDA et al., 2010).
Peanut grains contain about $45 \%$ of oil (KASAI et al., 1998), making it the fifth most consumed oleaginous crop, corresponding to $10 \%$ of the edible oil produced in the world (GODOY et al., 2004). Currently, besides the human consumption and edible oil extraction, peanut has a significant role as a plant, with potential for biodiesel since its seeds exceed the soybean oil content (GONÇALVES et al., 2004). 
Western Parana has become known for producing creeping peanut after the harvest of winter crops (wheat and second crop corn). The main varieties used by growers are originated in São Paulo, especially the Runner IAC 886 that is a creeping cultivar widely employed in Western Parana. However, the technical information for the cultivation in the state is still incipient, ignoring its response to fertilization. In this sense, the producers have implemented the crop without a basic fertilization, just taking advantage of the residual fertilization of the previous crop (first crop).

Regarding the cultivation development, Malavolta (1980) points out that despite being a plant of low nutritional requirement, its agronomic performance is directly dependent on the availability of nutrients in the soil. Calcium and phosphorus are essential for flowering and the development of pods and seeds, while $\mathrm{K}$ promotes the vegetative development (GASCHO; DAVIS 1995). However, the responses of peanut crop to fertilization with nitrogen, phosphorus, and potassium are contradictory, with reports of positive (THIMMEGOWDA 1993; MARUBAYASHI et al., 1997; BASU et al., 2008; HIPPLER et al., 2011), negative (GERIN et al., 1996; SPINOLA; CÍCERO 2002) and absence of responses (KASAI et al., 1998; GASCHO; PARKER 2006).

In recent growing seasons, it has been observed little variation regarding peanut cultivated area, but with increases in yield, mainly due to the introduction of new technologies (MIRANDA et al., 2010). However, the use of appropriate doses of $P$ and $\mathrm{K}$ can maximize the profitability in creeping peanuts cultivation. Thus, the aim of this study was to evaluate the basic fertilization with $\mathrm{P}$ and $\mathrm{K}$ on the grain yield and production components of creeping peanut.

\section{MATERIAL AND METHODS}

The experiment was performed in the agricultural area performing a succession planting, following the cultivation of soybean/corn. The trial was implanted from November 2008 to May 2009, in Maripá - PR, at Estância Zoz Farm, situated at $24^{\circ}$ $22^{\prime} 31$ "S latitude, $53^{\circ} 44^{\prime} 23^{\prime \prime}$ longitude and altitude of 380 meters.

The soil is classified as eutrudox Red Latossol, with a clayey texture and flat to slightly hilly topography (EMBRAPA, 2013). Before the experiment implementation, soil samples were collected within the $0-20 \mathrm{~cm}$ horizon and the chemical analysis showed the following results: $\mathrm{pH}$ in $\mathrm{CaCl} 2: 5.4$; O.M.$: 36.23 \mathrm{~g} \mathrm{dm}$ 3; P (Melich-1): $15.34 \mathrm{mg} \mathrm{dm}^{-3}$; K (Melich-1): 1.11 cmolc dm${ }^{-3}$; $\mathrm{Ca}(\mathrm{KCl}): 6.39$ cmolc $\mathrm{dm}^{-3} ; \mathrm{Mg}(\mathrm{KCl}): 2.26$ cmolc dm ${ }^{-3} ; \mathrm{H}+\mathrm{Al}: 5.54$ cmolc dm$^{-3}$; Al: 0.00 , cmolc $\mathrm{dm}^{-3}$ SB: 9.76, cmolc dm-3; CEC: 15.30, cmolc $\mathrm{dm}^{-3}$ and $\mathrm{V} \%: 64$.

The local climate is Cfa according to Köppen, characterized as subtropical and, the average annual rainfall for the region is between 1600 and $2000 \mathrm{~mm}$. Rainfall and temperature data during the experiment are in Figure 1A and 1B.

The experiment was performed in a randomized block design, in a $2 \times 3+1$ factorial scheme. Two doses of $\mathrm{K}\left(30\right.$ and $60 \mathrm{~kg} \mathrm{ha}^{-1}$ of $\mathrm{K}_{2} \mathrm{O}$ ) and three levels of $\mathrm{P}\left(60,90\right.$ and $120 \mathrm{~kg} \mathrm{ha}^{-1}$ of $\left.\mathrm{P}_{2} \mathrm{O}_{5}\right)$ at sowing and an additional treatment without the basic fertilization, with four replicates were applied. Potassium chloride and super triple phosphate were sources of $\mathrm{P}$ and $\mathrm{K}$, respectively. Each plot consisted of five rows spaced at $0.80 \mathrm{~m}$, six meters long. For the evaluations, the two sidelines and $0.5 \mathrm{~m}$ at each end were ignored.

For the nutrient doses definition, the fertilizer recommendations for low fertility soils were taken as the lower limit (SANTOS et al., 1997), and as the upper limit, it was considered the double to obtain responses to the high fertility soil.

Soil preparation was performed with subsoiling and harrowing. The furrows were manually opened in a row, and the fertilizers were deposited on the bottom of the grooves. After closing the furrows, the mechanized peanut sowing was performed. It was used the Runner IAC 886 creeping peanut cultivar. Initially, 12 seeds per meter were sown, and after the crop establishment, the thinning was performed, adjusting the population densities to seven plants per meter.

When was observed $60-65 \%$ of mature pods the plants were harvested. Ten plants were randomly selected within the useful area of the plot to make assessments of the number of pods per plant, number of pods with grains per plant, number of grains per pod and number of grains per plant. The difference between the total number of pods per plant and the number of pods with grains per plant was expressed as a percentage of pods without grain. The rest of the plot was threshed, cleaned, weighed and then corrected to $13 \%$ moisture to get the peanut pod yield. The grain yield was estimated from the collection of pods sample that has been peeled. One hundred grain weight was determined as described in RAS (BRASIL, 2009).

The results were submitted to analysis of variance by the $\mathrm{F}$ test. The means of the components of factorial treatments were compared by LSD test $(\mathrm{P}$ $\leq$ 0.05). Through the Dunnett test $(\mathrm{p} \leq 0.05$ ), orthogonal contrasts of factorial treatments were 

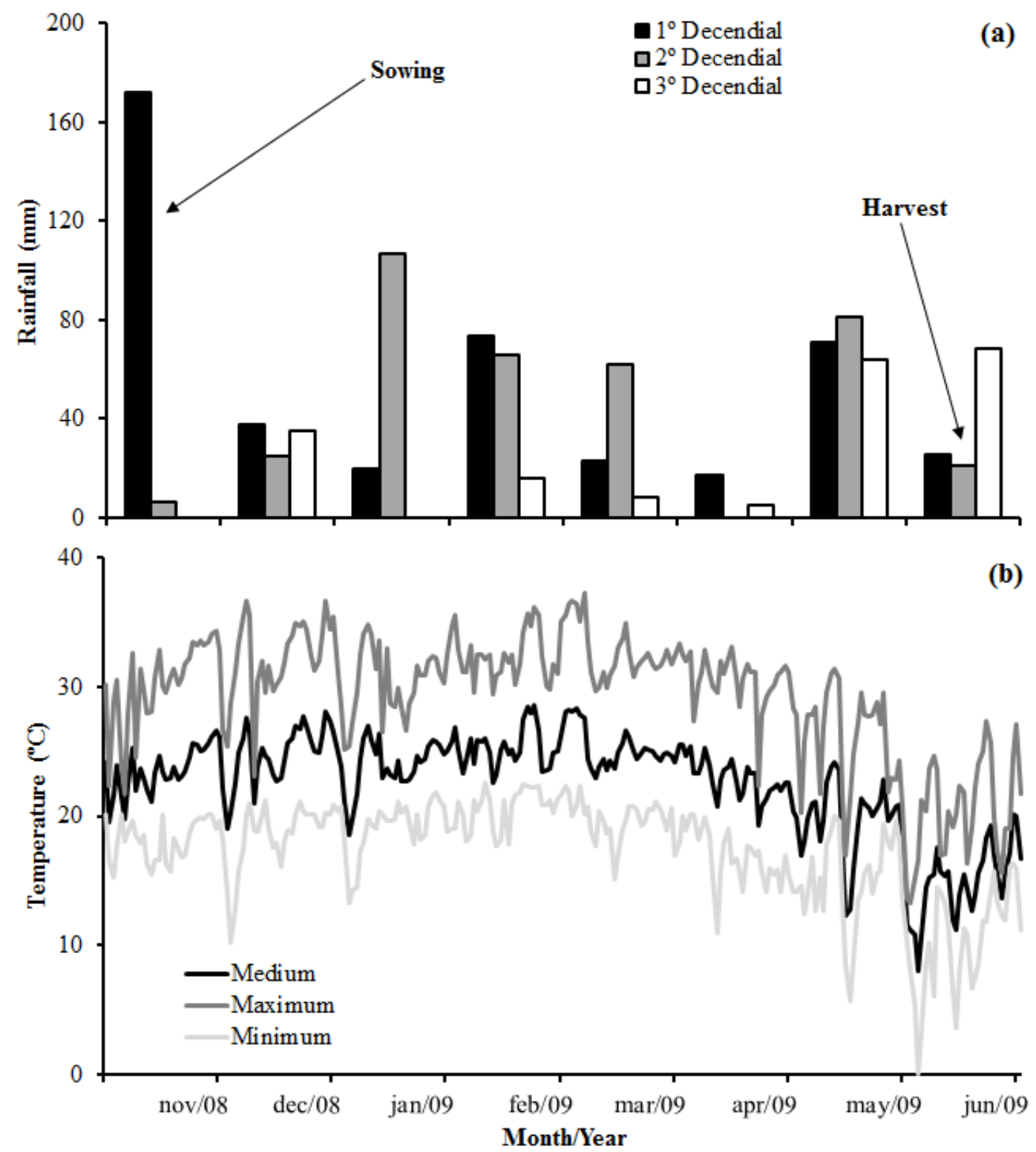

Figure I. Rainfall (a) and maximum, medium and minimum temperatures (b) during the experiment, Maripá - PR, 2009.

compared to the control. When there was a significant interaction by $\mathrm{F}$ test for the factorial, orthogonal contrasts between each treatment and the control were performed. For the variable in which the $F$ test detected the simple effect of factors, orthogonal contrasts between the means of each factor and the control were performed. When the F test found no significant effect for the factorial, the only orthogonal contrast between the mean factorial and the control was performed.

\section{RESULTS AND DISCUSSION}

K fertilization only influenced the percentage of pods with grains. There were no statistical differences for the other variables. The number of pods per plant, number of pods with grains, the percentage of pods without grains and the number of grains per pod were influenced only by the application of $\mathrm{P}$. For the interaction $\mathrm{K} x \mathrm{P}$, it was 
Table I. Analysis of variance (F values) obtained for pod yield (PY), grain yield (GY), number of pods per plant (NPP), number of pods with grains (NPG), the percentage of pods without grains grenades (PPWG), 100 grains weight $(100 \mathrm{GW})$ and number of grains per pod (NGP) of creeping peanut submitted to the application of $P$ and $K$ at sowing.

\begin{tabular}{cccccccc}
\hline S.V. & PY & GY & NPP & NPG & NPWG & $100 G W$ & NGP \\
\hline Potassium $(\mathrm{K})$ & $0.05^{\mathrm{ns}}$ & $0.48^{\mathrm{ns}}$ & $0.45^{\mathrm{ns}}$ & $0.04^{\mathrm{ns}}$ & $4.42^{*}$ & $0.00^{\mathrm{ns}}$ & $1.38^{\mathrm{ns}}$ \\
Phosphorus (P) & $3.29^{\mathrm{ns}}$ & $3.34^{\mathrm{ns}}$ & $22.51^{* *}$ & $38.48^{* *}$ & $31.00^{* *}$ & $0.47^{\mathrm{ns}}$ & $11.08^{* *}$ \\
K x P & $3.73^{*}$ & $0.08^{\mathrm{ns}}$ & $3.44^{\mathrm{ns}}$ & $1.01^{\mathrm{ns}}$ & $3.36^{\mathrm{ns}}$ & $6.18^{* *}$ & $1.07^{\mathrm{ns}}$ \\
Factorial x Adit. & $13.26^{* *}$ & $16.48^{* *}$ & $3.12^{\mathrm{ns}}$ & $3.91^{\mathrm{ns}}$ & $0.33^{\mathrm{ns}}$ & $6.49^{*}$ & $19.45^{* *}$ \\
\hline C.V. $(\%)$ & 11.62 & 15.75 & 13.80 & 15.42 & 16.94 & 5.94 & 1.96 \\
\hline
\end{tabular}

** and $*$ significant at 1 and $5 \%$ probability by the F test, respectively. ns - not significant; CV - coefficient of variation; SV - Source of variation.

Table II. Mean values for pod yield, grain yield and number of pods per plant in creeping peanut submitted to $\mathrm{P}$ and $\mathrm{K}$ application at sowing. The combination contrast of $\mathbf{P}$ and $\mathrm{K}$ compared to the control by Dunnett test.

\begin{tabular}{|c|c|c|c|c|}
\hline \multirow{2}{*}{$\mathrm{K}\left(\mathrm{kg} \mathrm{ha}^{-1}\right)$} & \multicolumn{3}{|c|}{$\mathrm{P}\left(\mathrm{kg} \mathrm{ha}^{-1}\right)$} & \multirow{2}{*}{ Mean } \\
\hline & 60 & 90 & 120 & \\
\hline & \multicolumn{4}{|c|}{------------------ Pod Yield $\left(\mathrm{kg} \mathrm{ha}^{-1}\right)$----------------- } \\
\hline 30 & $3847 \mathrm{aA}^{*}$ & $3122 \mathrm{aB}$ & 3836 aA* & 3602 \\
\hline 60 & $3221 \mathrm{bB}$ & $3586 \mathrm{aAB}$ & $3893 \mathrm{aA}^{*}$ & 3567 \\
\hline Mean & 3534 & 3354 & 3864 & 3584 \\
\hline \multirow[t]{2}{*}{ Additional Mean $=2791$} & & & & $\mathrm{~d}^{\prime}=807$ \\
\hline & \multicolumn{4}{|c|}{ 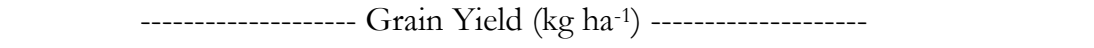 } \\
\hline 30 & 2316 & 1950 & 2129 & 2132 \\
\hline 60 & 2235 & 1796 & 2097 & 2043 \\
\hline Mean & 2275 & 1873 & 2113 & $2087^{*}$ \\
\hline \multirow[t]{2}{*}{ Additional Mean $=1400$} & & & & $\mathrm{~d}^{\prime}=479$ \\
\hline & \multicolumn{4}{|c|}{--- } \\
\hline 30 & 33.97 & 32.23 & 50.93 & 39.04 \\
\hline 60 & 43.56 & 30.37 & 47.63 & 40.52 \\
\hline Mean & $38.76 \mathrm{~B}$ & $31.30 \mathrm{C}$ & $49.28 \mathrm{~A}^{*}$ & 39.78 \\
\hline Additional Mean $=34.64$ & & & & $\mathrm{~d}^{\prime}=9,34$ \\
\hline
\end{tabular}

found that there was a significant effect in pod yield and 100 grains weight (Table 1). The interaction of factor and additional treatment affected pod yield, grain yield, 100 grains weight and in the number of grains per pod (Table 1).

Pod yield at a dose of $30 \mathrm{~kg} \mathrm{ha}^{-1} \mathrm{~K}$ had higher mean values when associated with doses of 60 and 120 $\mathrm{kg} \mathrm{ha}^{-1} \mathrm{P}$ (Table 2). However, with the application of $60 \mathrm{~kg} \mathrm{ha}^{-1} \mathrm{~K}$, a higher pod yield was observed with doses of $120 \mathrm{~kg} \mathrm{ha}^{-1} \mathrm{P}$ (Table 2). Regarding the additional treatment, combinations between doses of $30 \mathrm{~kg} \mathrm{ha}^{-1} \mathrm{~K}$ with 60 and $120 \mathrm{~kg} \mathrm{ha}^{-1} \mathrm{P} ; 60 \mathrm{~kg} \mathrm{ha}^{-1} \mathrm{~K}$ with $120 \mathrm{~kg} \mathrm{ha}^{-1}$ of resulted in pod yield growth of 1056, 1045 and $1102 \mathrm{~kg} \mathrm{ha}^{-1}$, respectively (Table 2).

The pod yield is considered high according to the classification proposed by Quaggio and Godoy (1996). About the grain yield, there was no influence of
$\mathrm{K}$ and $\mathrm{P}$ doses. However, the factorial was greater than the control in $687 \mathrm{~kg} \mathrm{ha}^{-1}$, demonstrating that the creeping peanut responds to phosphate and potassium fertilizer in the conditions of the study (Table 2). Basu et al. (2008), evaluating the peanut grain yield with different levels of fertilization, found that at all levels of NPK fertilization, the yield was significantly superior to the treatment without fertilization. These reports also corroborate the ones checked by Thimmegowda (1993), who also reported positive effects of NPK fertilization in peanut plants.

Feitosa et al. (1993) found an absorption of 10 $\mathrm{kg} \mathrm{ha} \mathrm{H}^{-1} \mathrm{P}$ and $52 \mathrm{~kg} \mathrm{ha}^{-1} \mathrm{~K}$, of which 59.4 and $32.7 \%$ were translocated to the grain, respectively, in creeping peanut cv.Penapolis.

Rodrigues Filho et al. (1988), studying the omission of macronutrients in peanut $\mathrm{cv}$. Tatu found a 
Table III. Mean values for the number of pods with grains, the percentage of pods without grains, 100-grain weight and number of grains per pod in creeping peanut submitted to $P$ and $K$ application at sowing. The combination contrast of $P$ and $K$ compared to the control by Dunnett test.

\begin{tabular}{|c|c|c|c|c|}
\hline \multirow{2}{*}{$\mathrm{K}\left(\mathrm{kg} \mathrm{ha}^{-1}\right)$} & \multicolumn{3}{|c|}{$\mathrm{P}\left(\mathrm{kg} \mathrm{ha}^{-1}\right)$} & \multirow{2}{*}{ Mean } \\
\hline & 60 & 90 & 120 & \\
\hline & \multicolumn{4}{|c|}{ 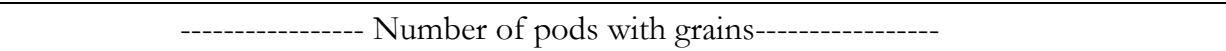 } \\
\hline 30 & 28.10 & 20.76 & 41.22 & 30.03 \\
\hline 60 & 31.33 & 19.33 & 38.32 & 29.66 \\
\hline Mean & $29.71 \mathrm{~B}$ & $20.05 \mathrm{C}$ & $39.77 \mathrm{~A}^{*}$ & 29.84 \\
\hline \multicolumn{4}{|l|}{ Additional Mean $=25.04$} & $\mathrm{~d}^{\prime}=7.79$ \\
\hline & \multicolumn{4}{|c|}{---------- Percentage of pods without grains $(\%)$---------- } \\
\hline 30 & 17.65 & 35.58 & 19.26 & $24.16 \mathrm{~b}$ \\
\hline 60 & 28.11 & 36.37 & 19.46 & $27.98 \mathrm{a}$ \\
\hline Mean & $22.88 \mathrm{~B}$ & $35.98 A^{*}$ & $19.36 \mathrm{~B}^{*}$ & 26.07 \\
\hline \multicolumn{2}{|l|}{ Additional Mean $=27.46$} & & d' $K=7.27$ & $\mathrm{~d}^{\prime} \mathrm{P}=7.71$ \\
\hline & \multicolumn{4}{|c|}{---o- 100-grain weight (g) -- } \\
\hline 30 & $110.3 \mathrm{bB}$ & $121.0 \mathrm{aA}^{*}$ & $111.5 \mathrm{aAB}$ & 114.2 \\
\hline 60 & $120.8 \mathrm{aA} *$ & $108.2 \mathrm{bB}$ & $113.3 \mathrm{aAB}$ & 114.1 \\
\hline Mean & 115.6 & 114.6 & 112.4 & 114.2 \\
\hline \multicolumn{4}{|l|}{ Additional Mean $=105.0$} & $\mathrm{~d}^{\prime}=134.0$ \\
\hline \multicolumn{5}{|c|}{----------- Number of grains per pod ---------- } \\
\hline 30 & 1.75 & 1.66 & 1.72 & 1.71 \\
\hline 60 & 1.73 & 1.67 & 1.68 & 1.69 \\
\hline Mean & $1.74 \mathrm{~A}$ & $1.66 C^{*}$ & $1.70 \mathrm{~B}^{*}$ & 1.70 \\
\hline Additional Mean $=1.78$ & 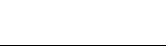 & & & $\mathrm{d}^{\prime}=0.06$ \\
\hline
\end{tabular}

reduction of $43 \%$ in the plant dry matter with $\mathrm{P}$ and $\mathrm{K}$ omission; they also observed a decrease of 35 and $43 \%$ for plant height with the omission of $\mathrm{P}$ and $\mathrm{K}$, respectively. The authors report that $\mathrm{P}$ deficiency in peanut plants culminate in a slight reduction in the growth and development of plants. However, K deficiency reduces the growth of plants; initially causing brown spots on the leaf edges, then affecting the entire leaf; subsequently, promotes the death of foliage and the leaves fall.

The total number of pods per plant was influenced only by $\mathrm{P}$ doses. The highest number of pods per plant was found with the application of 120 $\mathrm{kg} \mathrm{ha} \mathrm{h}^{-1} \mathrm{P}$. The greatest number of pods on the additional treatment was also observed with the application of $120 \mathrm{~kg} \mathrm{ha}^{-1} \mathrm{P}$; there were no differences for the other doses of P (Table 2). Zucareli et al. (2006) also found an increase in the number of pods per plant in bean crop with increasing doses of $\mathrm{P}$.

Doses of $\mathrm{P}$ only influenced the number of pods with grains and the highest values was observed with the application of $120 \mathrm{~kg} \mathrm{ha}^{-1} \mathrm{P}$. It was also found that the dose of $120 \mathrm{~kg} \mathrm{ha}^{-1} \mathrm{P}$ was the only one that differed from the additional treatment (Table 3).

Assessing the interaction between increasing doses of P and native mycorrhizal fungi, Hippler et al. (2011) concluded that phosphorus fertilization enhanced the development of peanut plants (Runner IAC 886), regardless the inoculation with native fungi. For Malavolta et al. (1997) the P function is related to energy production in plants, stored as adenosine triphosphate (ATP) and adenosine diphosphate (ADP). It is worth mentioning that as $\mathrm{P}$ promotes increased growth of peanut plants, there is an increase in the number of branches and, consequently, there is an increase in the number of pods per plant.

The highest percentage of pods without grains among doses of $\mathrm{K}$ was observed at a dose of $60 \mathrm{~kg} \mathrm{ha}$ ${ }^{1}$, whereas among the doses of P, it was observed at a dose of $90 \mathrm{~kg} \mathrm{ha}^{-1}$ (Table 3). Regarding the additional treatment, there was no difference among the doses of $\mathrm{K}$; however, for $\mathrm{P}$ doses, it was found that with the 
application of $120 \mathrm{~kg} \mathrm{ha}^{-1}$, the percentage of pods without grains was significantly lower than the control (Table 3).

For 100 grains weight, there was no influence of the interaction between doses of $\mathrm{P}$ and $\mathrm{K}$. It was found a greater 100 grains weight with the combined application of $60 \mathrm{~kg} \mathrm{ha}^{-1} \mathrm{~K}+60 \mathrm{~kg} \mathrm{ha}^{-1} \mathrm{P}$ and also 30 $\mathrm{kg} \mathrm{ha}{ }^{-1} \mathrm{~K}+90 \mathrm{~kg} \mathrm{ha}^{-1} \mathrm{P}$ (Table 3). The 100 grains weight of the reported combinations was also significantly higher than the 100 grains weight of the control (Table 3 ). The results confirm that $\mathrm{K}$ supply to peanuts at sowing is enough to provide the crop in the periods with higher nutrient demand which occurs from the 30th to the 55th day after sowing (Miranda et al., 2010). Marubayashi et al. (1997) studying P fertilization on the yield of three varieties and two peanut strains, verified an increase in the 100 grains weight with $\mathrm{P}$ application on a cultivar and both strains.

The lower values for the 100 grains weight with the application of $30 \mathrm{~kg} \mathrm{~K}+60 \mathrm{~kg} \mathrm{P}$ and $60 \mathrm{~kg} \mathrm{~K}$ $+90 \mathrm{~kg} \mathrm{P}$ compared to other fertilizers and their similarity to the additional treatment are consistent with the results obtained by Spinola and Cicero (2002). The authors did not report positive effects of $\mathrm{P}$ and $\mathrm{K}$ fertilization in peanut at sowing on the 100 grains weight.

The number of grains per pod was affected by doses of $\mathrm{P}$, reaching the highest value at a dose of 60 $\mathrm{kg} \mathrm{ha}^{-1}$ with similar means to the additional treatment. This result is consistent with the one obtained by Nakagawa (2000) who attributed the higher crop yield to the contribution of $\mathrm{P}$ that is in the soil. The additional treatment showed a greater number of grains per pod at doses of 90 and $120 \mathrm{~kg} \mathrm{ha}^{-1} \mathrm{P}$ (Table 3).

There are more pronounced responses to the doses of $\mathrm{P}$ possibly due to the high content of $\mathrm{K}$ in the soil $\left(1.11 \mathrm{cmol}_{\mathrm{c}} \mathrm{dm}^{-3}\right)$. This is also reported by Machado et al. (2005) who studied peanut production of forage fertilized with different combinations of $\mathrm{K}$ and $\mathrm{P}$ in an Albaqualf. The authors concluded that the dry matter production of the phosphate fertilizer is more crucial than the potassium one, attributing this result to the average content of $K$ in the soil $(0.32$ $\mathrm{cmol}_{\mathrm{c}} \mathrm{dm}^{-3}$ ). For Kerridge (1995), peanut responds to $\mathrm{K}$ doses on dry matter yield only when the exchangeable $\mathrm{K}$ in the soil is low.

\section{CONCLUSION}

Fertilization with $\mathrm{P}$ and $\mathrm{K}$ promotes an increase of 38 and $49 \%$ in the pod and grain yield, respectively. The greatest values of pods with grains are verified with the application of $120 \mathrm{~kg} \mathrm{ha}^{-1} \mathrm{P}$.

\section{REFERENCES}

BASU, M.; BHADORIA, P. B. S.; MAHAPATRA, S. C. Growth, nitrogen fixation, yield and kernel quality of peanut in response to lime, organic and inorganic fertilizer levels. Bioresource Technology, New York, v. 99, n. 11, p. 4675-4683, 2008.

BRASIL - Ministério da Agricultura e Reforma Agrária. Regras para análise de sementes. Brasília, Secretaria Nacional de Defesa Agropecuária, 398p., 2009.

CAVIGLIONE, J. H.; KIIHL, L. R. B.; CARAMORI, P. H. OLIVEIRA, D. Cartas climáticas do Paraná. Londrina: IAPAR, 2000.2 Disponível em:http://iapar.br/modules/conteudo/conteudo.php? conteudo=677. Acesso em: 17 jul. 2017.

EMBRAPA - Empresa Brasileira de Pesquisa Agropecuária. Centro Nacional de Pesquisa de Solos. Sistema Brasileiro de Classificação de Solos. 3 ed. Brasília: Embrapa Solos, 353p, 2013.

FEITOSA, C. T.; NOGUEIRA, S. S. S.; GERIN, M. A. N.; RODRIGUES FILHO, F. S. O. Avaliação do crescimento e da utilização de nutrientes pelo amendoim. Scientia Agricola, Piracicaba, v. 50, n. 3, p. 427-437, 1993.

GASCHO, G. J.; PARKER; M. B. Nitrogen, Phosphorus, and Potassium Fertilization of a Coastal Plain Cotton-Peanut Rotation. Communications in Soil Science and Plant Analysis, Athens, v. 37, n. 9/10, p. 1485-1499, 2006.

GASCHO, G. J.; DAVIS, J. G. Soil fertility and plant nutrition. In: PATEE, H. E.; STALKER, H. T. (Eds.). Advances in peanut science. Stillwater: American Peanut Research and Education Society, p. 383-419, 1995.

GERIN, M. A. N.; FEITOSA, C. T.; RODRIGUES FILHO, F. S. O.; PEREIRA, J. C. V. N. A.; NOGUEIRA, S. S. S.; IGUE, T. Adubação do amendoim (Arachis hypogaea 1.) em área de reforma de canavial. Scientia Agricola, Piracicaba, v. 53, n. 1, p. 8487, 1996. 
GODOY, I. J. Melhoramento do amendoim. In: BORÉM A. (Ed.). Melhoramento de espécies cultivadas. Viçosa: Universidade Federal de Viçosa - UFV, 51102, 2004.

GONÇAVES, J. A.; PEIXOTO, C. P.; LEDO, C. A. S. Componentes de produção de amendoim em diferentes arranjos espaciais no Recôncavo Baiano. Revista Brasileira de Oleaginosas e Fibrosas, Campina Grande, v. 8, n. 2, p. 801-812, 2004.

HIPPLER, F. W. R.; MOREIRA, M.; DIAS, N. M. S.; HERMANN, E. R. Fungos micorrízicos arbusculares nativos e doses de $\mathrm{P}$ no desenvolvimento do amendoim RUNNER IAC 886. Revista Ciência Agronômica, Fortaleza, v. 42, n. 3, p. 605-610, 2011.

KASAI, F. S. ATHAYDE, M. L. F.; GODOY, I. J. Adubação fosfatada e épocas de colheita do amendoim: efeitos na produção de óleo e de proteína. Bragantia, Campinas, v. 57, n. 1, p. 163-168, 1998.

KERRIDGE, P. C. Biología y agronomía de espécies forrajeras de Arachis. Cali: Centro Internacional de Agricultura Tropical (CIAT). 227p., 1995.

MACHADO, N. A.; SIEWERDT, L.; VAHL, L. C.; FERREIRA, O. G. L. Estabelecimento e produção de amendoim-forrageiro em campo natural de Planossolo, sob diferentes níveis de fósforo e potássio. Revista Brasileira de Agrociência, Pelotas, v. 1, n. 4, p. 461-466, 2005.

MALAVOLTA E. Elementos de nutrição mineral de plantas. São Paulo: Agronômica Ceres. 251p., 1980.

MALAVOLTA, E.; VITTI, G. C.; OLIVEIRA, S. A. Avaliação do estado nutricional das plantas, principios e aplicações. 2. ed. Piracicaba: Potafos, 319p., 1997.

MARUBAYASHI, O. M.; ROSOLEM, C. A.; NAKAGAWA, J.; ZANOTTO, M. D. Adubação fosfatada, produção e qualidade de sementes de populações de amendoim. Pesquisa Agropecuária Brasileira, Brasília, v. 32, n. 9, p. 885-892, 1997.
MIRANDA, J. H.; BÉRGAMO, L. R.; REIS, J. B. R. S.; CRUCIANI, D. E.; DUARTE, S. N. Distribuição da concentração de potássio no solo em lisímetros cultivados com amendoim. Engenharia Agrícola, Jaboticabal, v. 30, n. 2, p. 253-262, 2010.

NAKAGAWA J.; LASCA. D. C.; NEVES. G. S.; NEVES. J. P. S.; SILVA. M. N.; SANCHEZ, S. V.; BARBOSA, V.; ROSSETTO, C. A. Densidade de plantas e produção de amendoim. Scientia Agricola, Piracicaba, v. 57, n. 1, p. 67-73, 2000.

NAKAGAWA, J.; ROSOLEM, C.; MACHADO, J. R. Efeitos da adubação fosfatada no vigor das sementes de amendoim. Revista Brasileira de Sementes, Brasília, v. 2, n. 1 , p. $67-74,1980$.

QUAGGIO, J. A.; GODOY, I. J. Amendoim. In: RAIJ, B.; CANTARELlA, H.; QUAGGIO, J. A.; FURLANI A. M. C. Recomendações de adubação e calagem para o Estado de São Paulo. Campinas: IAC. p.192 (Boletim Técnico, 100).

RODRIGUES FILHO F.S.O. FEITOSA C.T. \& GERIN M.A.N. Omissão de macronutrientes em plantas de amendoim. Bragantia, Campinas, v. 47, n. 2, p. 305-312, 1988.

SANTOS, R. C.; AZEVEDO, D. M. P.; ALVES, N. S.; SANTOS, V. F. Nova recomendação de espaçamento de amendoim: Boletim de pesquisa 32. Campina Grande: Embrapa Algodão. 19 p, 1997.

SPINOLA, M. C. M; CICERO, S. M. Qualidades física e fisiológica de sementes de amendoim submetidas a doses de gesso agrícola combinadas a épocas e modos de aplicação: II. Área sem calagem. Revista Brasileira de Sementes, Londrina, v. 24, n. 1, p. 229-236, 2002.

THIMMEGOWDA, S. Effect of residual fertility and direct fertilization on kernel, protein and oil yield of peanut (Arachis hypogaea L) grown in rice fallows. Journal of the Science of Food and Agri Crop, Weinheim, v. 61, p. 385-387. 1993.

ZUCARELI, C.; RAMOS JUNIOR, E. U.; BARREIRO, A. P.; NAKAGAWA. J.; CAVARIANI C. Adubação fosfatada, componentes de produção, produtividade e qualidade fisiológica em sementes de feijão. Revista Brasileira de Sementes, Pelotas, v. 28, n. 1, p. 9-15, 2006. 